Review on Agriculture and Rural Development 2019 vol. 8 (1-2) ISSN $2677-0792$

\title{
MORPHOMETRIC AGE AND SEX IDENTIFICATION OF EURASIAN COLLARED DOVES (STREPTOPELIA DECAOCTO FRIV.) - A PILOT-TEST
}

\author{
SÁMUEL ZSOLT VARGA - LAJOS JUHÁSZ \\ University of Debrecen Faculty of Agricultural and Food Sciences and Environmental \\ Management Department of Nature Conservation Zoology and Game Management, \\ 138. Böszörményi út, Debrecen, Hungary 4032 \\ varga.samuel@agr.unideb.hu
}

\begin{abstract}
In this research, our main goal was to test, if there is an effective, yet economical way to perform native sexing on Columbidae species in field conditions. Since molecular sexing is not available among field conditions, a morphometric method was aimed to be used. After morphometric measurements, autopsy was performed to determine the sex of collected birds. The novelty of the method is that we added a new measure point to improve age and sex determination. The method was tested on Eurasian Collared Doves $(n=18)$. Our result showed that the gap of pubic bones is highly correlated to age and most of the main morphometric data, despite the low sample number.
\end{abstract}

Keywords: age determination, sex determination, columbids, morhometrics

\section{INTRODUCTION}

Accurate sex identification is an important factor in managing and studying both wild and captive animals. Usually it is not easy to specify the sex of most bird species before maturity, but in monomorphic species, it is difficult even after puberty. Many studies on sex identification in birds was focused on species with significant sexual dimorphism in such factors as size, plumage colouration, or parental ornamentation. (SOUTH AND WRIGHT, 2002). Birds are usually sexed by plumage pattern or morphological differences, gonadal inspection by laparoscopy, and more frequently by chromosome analysis techniques. (GARCELON et al, 1985). Several sexing methods were introduced to ornithology in the past few decades, instead of vent sexing, which is an old method popularized in the 1930s by a Japanese professor, Kiyoshi Masui. Vent sexers could easily get 95\% accurate results in sexing. (CERIT AND AVANUS, 2007). However, non-specialist people that learned the basic techniques of this method would be doing well to obtain $60-70 \%$ accuracy at best, even though specialists could be wrong in identifications (BRAMWELL, 2003). Since molecular and DNA-based sexual determination has gained popularity, morphometric methods are used as complementary procedures in sex determination. However, molecular methods became simpler; in some cases, morphometric procedures are preferred instead of genetic methods. By adding morphometric factors to the modern DNA-based sexing of adult Chinstrap Penguins ( $P$. antarctica) and adult and juvenile Gentoo Penguins ( . papua) became easier. Bill length and depth were the most consistent dimorphic character examined, on average male bill records were 5.4-11.5\% larger than females. (POLITO ET AL. 2012).

According to HENRY et al. (2015) morphological measurements of a South African sturnid indicated that males were statistically larger than females for four measurements: Mass, tail length, tarsus length and wing length. All individuals involved was previously tested by a DNA-based sexing method. These methods can be used simultaneously during field 
and laboratory work. The availability and effectiveness of each methods varies among species. There are species that only a small amount of morphometric data was needed to predict precisely the sex of an individual (MANWHINNEY AND DIAMOND, 1999).

Eurasian Collared Dove is a widespread bird species in Europe. Its range was set from the Middle East to Rear India, where four subspecies were expanded (GLUTZ AND BAUER, 1980; CRAMP, 1985). The expansion began in the early 1920's, the first Hungarian observation set in 1926, in Tiszaug (46.8537215 N, 20.052921 E) (BANKOVICS, 1984), its first nesting was dated in 1932 in Berettyóújfalu $(47.2196438 \mathrm{~N}, 21.5362811 \mathrm{E})$ (GRESCHIK, 1933). From the 1950's -except in closed forests- the Collared Dove became widespread in Hungary (KEVE-KLEINER, 1944; KEVE, 1950, 1962). The species colonized several part of Western Europe; the expansion of the species was extremely intensive in the European parts of the former Soviet Union (BOZSKO, 1976; HENGEVELD in HAGELMEIJER AND BLAIR, 1997). The reason of this phenomenon still has not finished: in Algeria the Collared Dove had become common in urban habitats in within a few years then reached agricultural lands in 2006 (BENDJOUDI et al., 2015). The breeding population of the Eurasian Collared Dove was estimated 100.000-300.000 individuals at the end of the 20th century in Hungary (MAGYAR et al., 1998). In the case of this species, age and sex determination has several difficulties, since these is no sexual dimorphism in feather pattern. BOZSKO (1983) showed that there is significant difference between males and females in wing length, but this cannot be a precise sexing method, because of the annual molt of feathers. Some monomorphic avian species were successfully sexed by morphometric measurements (SHUGART 1977, REESE AND KADLEC 1982, SKEEL 1982, SCOLARO et al. 1983).Mostly in cases of predators such as eagles individuals were identified using external characteristics (HELANDER, 1981). If the examined species has no sexual dimorphism, behavioral and psychical characters were recorded to identify the sex of an individual. Application of morphometric analyses becomes more complicated especially when the body size and feather colour vary among differing geographical regions (KAHN ET AL., 1998; SHEPHARD ET AL., 2004).

The modern Hungarian game management has set the goal of sustainability; therefore, the management with Eurasian Collared Dove should keep sustainability directives in mind. The first step is to reveal the exact age and sex distribution of populations, to precisely plan the annual bags in hunting sites, and prevent overhunting. This research was made to create the practical basis of the management of Eurasian Collared Doves, by the attempt of creating a quick method of monitoring population parameters that can be used by professional hunters in field conditions.

\section{MATERIAL AND METHOD}

\section{Data collection}

In August 2018, 18 Eurasian Collared Doves were collected from hunting bags in Nyíregyháza, Hungary. All individuals were identified by age-specific plumage characteristics and set into age classes (juvenile, $n=4$; adult, $n=14$ ). In order to contrast size differences between sexes the following morphometric data was recorded:

Mass (g)

Wing length $(\mathrm{mm})$

Full body length (mm) 


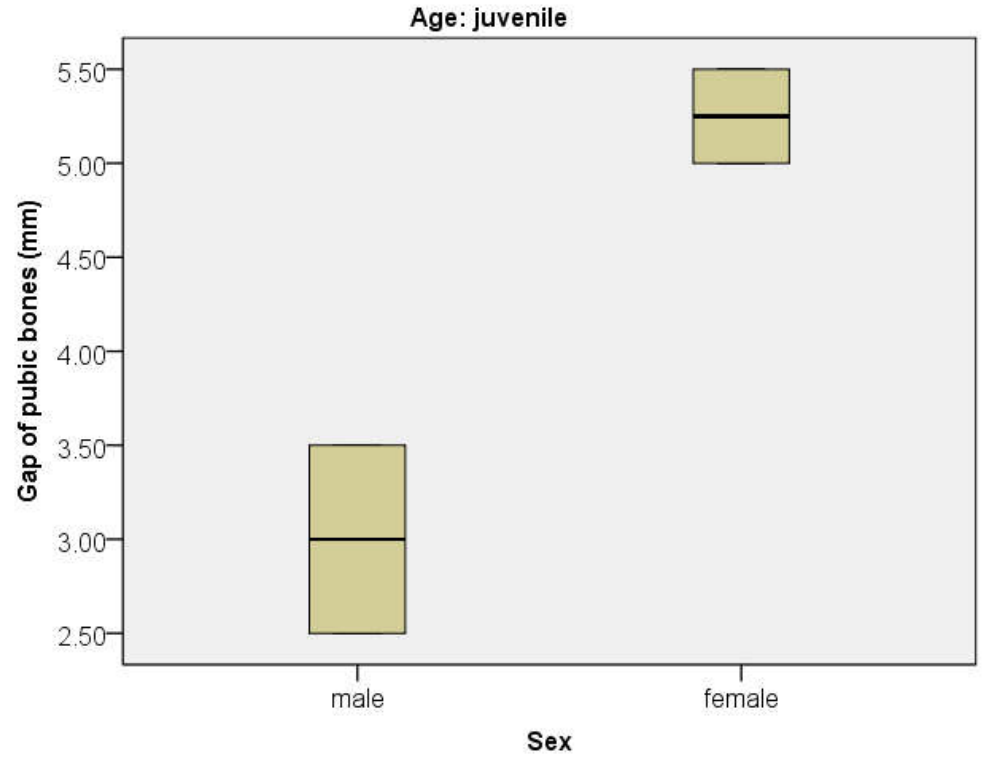

Figure 1. : Gap of pubic bones distribution of among sexes in juvenile age

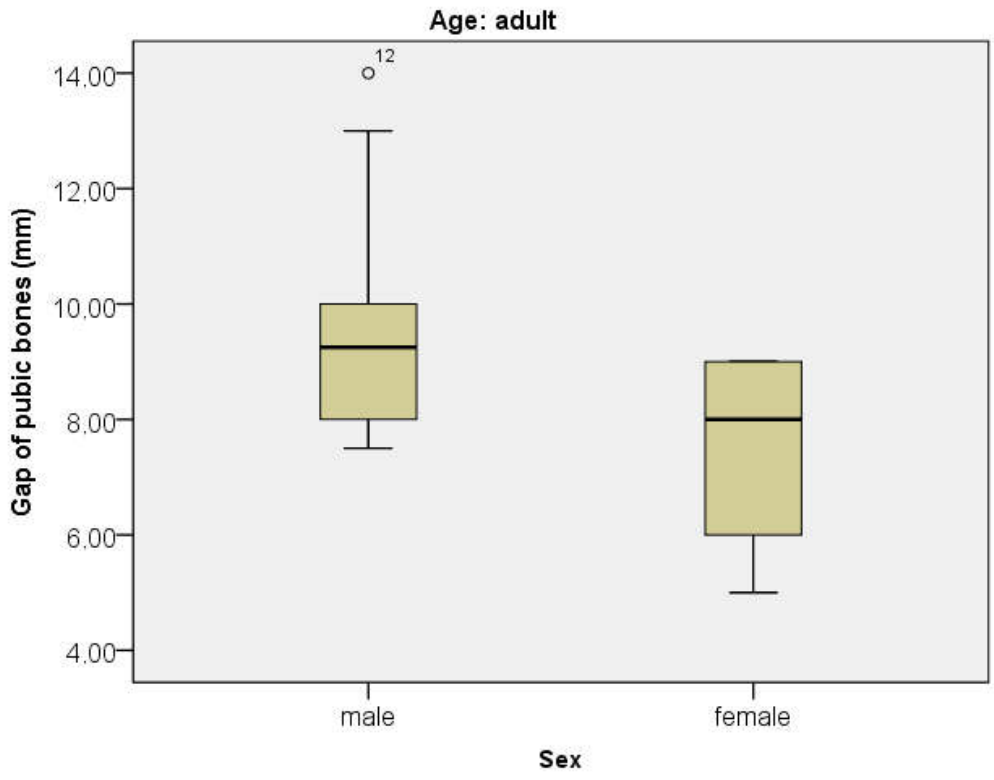

Figure 2. : Gap of pubic bones distribution among sexes in adult age

\section{DISCUSSION}

\section{Sexing methods- pros and contras}

Morphometric determination has a practical advantage, especially on field. A bird caught by a ringer shall be identified by age and sex immediately. This method is easily repeatable, simple, and safe, and finally yet importantly, no pain is caused during examination. However, classic surgical examination has the advantage of immediate result but a high risk of unwanted consequences, e.g. trauma caused during examination is expressed. In comparison hormonal sex determination has major advantage as it is a noninvasive collection of fecal droppings, no handling of bird are needed, so no stress was caused. The disadvantages of this method is that immature birds has low hormone 
production, making this method inapplicable for them. Chromosomal sexing can be applied to birds of any age or condition, if mitotic cells can be isolated and examined. The genetic sex of a bird, irrespective of behavioral or functional characteristics is identified by this method. Genetic sexing technical difficulties are concerned in culturing and isolating complete bird chromosome patterns and lack of available labs working with avian samples. Handling and restraint are necessary in the collection of blood or pin feather samples, which can result in stress and trauma to the bird. The transportation of blood samples to a lab may also be difficult for they must be protected from temperature extremes and begin analysis procedures within 24 hours after collection (BERCOWITZ, 1981). In a research carried out by GARCELON ET AL. (1985) more sexing methods were compared such as morphometric, karyotypic, and laparoscopic techniques on Bald Eagles. All three technique was reviewed and compared to contrast differences is time consumption and effectiveness. By using karyotypic procedure prescribed doses of anesthesia a working time of approximately 30 minutes was provided, with an additional 4 hours required for full recovery. Laparoscopy was performed in approximately 5 minutes, and approximately 20 minutes were required to make all of the measurements. During morphometric data collection, twelve measurements were taken on the birds, and only one showed no overlap in values between the sexes Three additional measurements had little overlap between the outlying extremes of the sexes but none in the $25-75$ percentile.

\section{The practical importance of the research}

Since Hungarian game management is coping with the problems of decreasing small game populations, wildlife managers seek alternatives to fulfill the demand of hunters. Eurasian Collared Doves are presented in high densities, apart from some regional exceptions; its populations are stable and expanding. Dove hunting is preferred by foreign hunters, because they are fast fliers and hard to shoot. In some regions, they are also served as local gastronomic specialty. The most important economic advantage is that Eurasian Collared Doves need no external input e.g. feeding sites, rural development etc., because they are nesting in human-altered habitats. The only disadvantage appears in summer season, when individuals are leaving towns and cities, causing high damage in agricultural fields, especially in sunflower (Helianthus annuus).

\section{ACKNOWLEDGEMENTS}

The publication is supported by the EFOP-3.6.3-VEKOP-16-2017-00008 project. The project is co-financed by the European Union and the European Social Fund.

\section{REFERENCES}

BANKovicS, A. (1984): Újabb adat a Balkáni gerle (Streptopelia decaocto) hazai megjelenéséhez. Aquila 91: 198.

Bendjoudi, D., Voisin, J., F., Doumandu, S., Merabet, A., Benyounes, N., Chenchouni, H. (2015): Rapid increase in numbers and change of land $\square$ use in two expanding Columbidae species (Columba palumbus and Streptopelia decaocto) in Algeria, Avian Research 6:18-26.

BERCOWITZ, A., B. (1981): BIRD SEXING METHODS which should you choose?, AFA Watchbird 8:18-20. 
BozsKo, Sz. (1983): The sex and age distribution as well as the major anato-morphological characteristics of the population of Collared Doves (Streptopelia decaocto Friv.) Aquila 90: 95-104.

BozSKO, Sz., I. (1976): A balkáni gerle (Streptopelia decaocto Friv.) expanziója a Szovjetunió területén. Állattani Közlemények 63: 61-65.

BRAMWELL, R.K. (2003) Sexing chicks in the backyard flock. Avian Advice 5: 4-5.

Cerit, H., Avanus, K. (2007): Sex identification in avian species using DNA typing methods, World's Poultry Science Journal 63: 91-99.

CRAMP, S. (1985): The Birds of the western Palearctic. 4. Oxford, University Press, Oxford Garcelon, D.,K., Martell, M.,S., Redig, P.,T., Buøen, L.,C. (1985): Morphometric, Karyotypic, and Laparoscopic Techniques for Determining Sex in Bald Eagles, The Journal of Wildlife Management 49: 595-599.

GlutZ Von Blotzheim, U., N.,BAuer, K., M. (1980): Handbuch der Vögel Mitteleuropas. Band 9. Columbiformes - Piciformes. Akademische Verlagsgesellschaft, Wiesbaden

GRESHIK, J. (1933): A balkáni kacagógerle, Streptopelia decaocto decaocto (Friv.) Berettyóújfaluban, Kócsag 1-2: 54-56.

HagemeiJer, W., J., M.,Blair, M., J. (1997): The EBCC Atlas of European Breeding Birds: Their distribution and abundance. T and D Poyser, London

Helander, B. (1981): Nestling measurements and weights from two white-tailed eagle populations in Sweden. Bird Study 28:235

Henry, L., Guyot-Biquand, V., Craig, A., J., F,. K., Hausberger, M. (2015): Sexing Adult Pale-Winged Starlings Using Morphometric and Discriminant Function Analysis. PLoS ONE, Public Library of Science, 2015, 10 (9) pp.e0135628.

KAHN, N., W., JOHN, J., QUINN, T. (1998): Chromosome-specific intron size differences in the Avian CHD gene provide an efficient method for sex identification in birds. The Auk 115: 1074-1078.

KEVE, A., (1950): Further notes on the range-increasing and ecology of the indian ringdove. Aquila, 51-54: 116-122.

Keve, A., (1962): The Collared Turtle-Dove in Hungary. Aquila 67-68: 71-78.

KeVE-Kleiner, A. (1944): Die Ausbreitung der orientalischen Lachtaube in Ungarn im letzten Dezennium. Aquila 50: 264-298.

Magyar, G., Hadarics, T., Waliczky, Z., Schmidt A., Bankovics, A. (1998): Nomenclator Avium Hungariae. MME- Winter Fair. Budapest-Szeged

MAWHINNEY, K., DiAmOND, T. (1999): Sex Determination of Great Black-Backed Gulls Using Morphometric Characters, Journal of Field Ornithology 70: 206-210.

Polito, M., J., Clucas, G., V., Hart, T., Trivelpiece, W., Z., (2012): A simplified method of determining the sex of Pygoscelis penguins using bill measurements. Marine Ornithology 40: 89-94.

Reese, K., P., Kadlec J., A. (1982): Determining the sex of Black billed Magpies by external measurements. Journal of Field Ornithology 53:417-419.

Scolaro, J., A., Hall, M., A., Ximenez, I., M. (1983). The Magellanic Penguin (Spheniscus magellanicus): sexing adults by discriminant analysis of morphometric characters Auk 100:221- 224.

Shephard, J., M., Catterall, C., P., Hughes, J, .M. (2004): Discrimination of sex in the whitebellied sea-eagle, Haliaeetus leucogaster, using genetic and morphometric techniques. Emu 104: 83-87.

SHUGART, G., W. (1977): A method for externally sexing gulls. Bird Banding 48:118-121. SKEEL, M., A. (1982): Sex determination of adult whimbrels. Journal of Field Ornithology. 53:414-416. 
South, J., M., Wright, T., M. (2002): Nestling sex ratios in the yellow-naped amazon: no evidence for adaptive modification. The Condor 104: 437-440. 